\title{
高強度乱流予混合火炎の構造*
}

\author{
店 橋 護 ${ }^{* 1}$, 於 云 林 $^{* 2}$, 宮内 敏 雄 ${ }^{* 1}$
}

\section{Structure of High Intensity Turbulent Premixed Flames}

\author{
Mamoru TANAHASHI, Yunlin YU and Toshio MIYAUCHI*3 \\ ${ }^{* 3}$ Dept. of Mechano-Aerospace Engineering, Tokyo Institute of Technology, \\ 2-12-1 Ookayama, Meguro-ku, Tokyo, 152-8552 Japan
}

\begin{abstract}
Direct numerical simulations of hydrogen-air turbulent premixed flames propagating in twodimensional homogeneous isotropic turbulence are conducted to investigate the effects of turbulence intensity on the structure of turbulent premixed flames. Detailed kinetic mechanism including 12 reactive species and 27 elementary reactions is used to simulate $\mathrm{H}_{2}-\mathrm{O}_{2}-\mathrm{N}_{2}$ reaction in turbulence. DNS are conducted for the cases of turbulent intensities of $10.0,20.0$ and 30.0 times of the laminar burning velocity. Turbulent burning velocity increases with the increase of turbulence intensity. The flame fronts for the case of lowest turbulence intensity can be classified in the regime of 'wrinkled laminar flame', whereas those for the cases of higher turbulence intensities show the characteristics of 'distributed reaction zone'. The mean flame thickness increases and the mean heat release rate decreases with the increase of turbulence intensity. However, for the higher intensity cases, variances of local flame thickness and heat release rate become large where the minimum local flame thickness decreases and the maximum local heat release rate increases with the increase of turbulence intensity. The local flame thickness and local heat release rate are well correlated with the tangential strain rate at the flame front.
\end{abstract}

Key Words: Computational Fluid Dynamics, Numerical Analysis, Turbulence, Combustion, Premixed Flame, Direct Numerical Simulation, Detailed Kinetic Mechanism

\section{1. 緒 論}

乱流予混合火炎は、ガスタービン燃焼器等の多くの 燃焼器で頻繁に観察される現象であり，これらの詳細 な構造を解明し，高精度乱流燃焼モデルを構築するこ とは，高効率燃焼器の設計・開発において非常に重要 である。従来，乱流予混合火炎の特性は，層流燃焼速 度 $\left(S_{L}\right)$ に対する乱流強度 $\left(u^{\prime}{ }_{m s}\right)$ の比及び層流火炎厚さ $\left(\delta_{\mathrm{L}}\right)$ に対する乱流場の特性長さ(積分長: $\left.l\right)$ の比を用いて 分類可能であると考えられている. $u^{\prime}{ }_{m s} / S_{L}$ と $l / \delta_{L}$ の関 係から, 乱流予混合火炎の形態は wrinkled laminar flames や distributed reaction zone 等に分類される(1)(2). wrinkled laminar flames の領域では，局所的な火炎要 素の特性は層流火炎と同じであり，火炎面面積の増大 によって乱流燃焼速度が増加すると考えられている。 これに対して, distributed reaction zone の領域では, 局所的な火炎要素の特性は層流火炎と全く異なってお り，もはや火炎面と呼べる構造は存在しないものと考 えられている。しかし，実際に distributed reaction

\footnotetext{
* 原稿受付 2000 年 1 月 19 日.

*1 正員, 東京工業大学工学部（画152-8552 東京都目黒区大岡 山 2-12-1).

*2 東京工業大学大学院.

E-mail : tmiyauch@mes.titech.ac.jp
}

zone が存在することは検証されておらず,それらの詳 細な構造も明らかにされていない。これは， $u^{\prime}{ }_{r m s} / S_{L}$ と $l / \delta_{\mathrm{L}}$ の関係を系統的に変化させた実験を行い，局所 的な火炎構造を計測することが困難であるためである。 近年, 計算機の高速・大容量化に伴い, 詳細化学反 応機構と輸送係数・物性值の温度依存性を考慮に入れ た乱流燃焼の直接数值計算(DNS)が可能となり, 乱流 中での火炎構造を詳細に検討することが可能となって きている. Baum ら (3) $^{(3)}$ 詳細化学反応機構を用いて水 素 ・酸素乱流予混合火炎の DNS を行い, 局所火炎構 造に対する化学反応機構の影響を明らかにするととも に, 乱流強度や乱流の特性長さ等の乱流場の特性と乱 流火炎の局所構造との関係を明らかにしている。著者 らは, 詳細化学反応機構を用いて水素 ·空気乱流予混 合火炎の DNS を行い, 局所火炎構造と化学種の拡散 係数の関係(4)(5)や火炎面のフラクタル特性 ${ }^{(4)}$ な゙を明ら かにするとともに，それらに対する当量比や予熱温度 の影響(6)(7)を明らかにした。また，Echekki と Chen ${ }^{(8)}$ は 4 段階の簡略化学反応機構を用いたメタン・空気乱 流予混合火炎の DNS 結果に同様な解析を行い, メ夕 ン・空気乱流予混合火炎の局所構造を明らかにしてい る.さらに,彼らは詳細化学反応機構を用いてメタン。 
空気乱流予混合火炎の DNS を行い，既然ガス中での 未燃予混合気塊の生成機構を明らかにしている(9). 最 近では，プロパンやメタンの詳細化学反応機構を考慮 に入れた DNS ${ }^{(10)(11)}$ や詳細化学反応機構を用いた水 素·空気乱流予混合火炎の三次元 $\mathrm{DNS}^{(12)(13)}$ も報告され ている.

乱流燃焼の DNS では， $u^{\prime}{ }_{r m s} / S_{L}$ と $l / \delta_{L}$ の関係を系統 的に変化させることが可能であるが，上述の多くの DNS は比較的低乱流強度の場合を対象としており, distributed reaction zone の存在の有無を検証し, その 構造を明らかにするまでには至っていない。そこで， 本研究では, 高乱流強度の水素·空気乱流予混合火炎 を対象として, 詳細化学反応機構と輸送係数・物性值 の温度依存性を考慮に入れたDNSを行い, 乱流強度 が火炎構造に与える影響を明らかにすることを目的と している.

\section{2. 記 号}

$a_{t}$ : 接線方向の歪み速度

$B_{k}$ : 素反応 $k$ の頻度因子中の定数 $c_{p, i}, c_{v, i}$ ：化学種 $i$ の定圧比熱と定積比熱

$D_{i m}$ : 混合気に対する化学種 $i$ の拡散係数

$E_{k}$ ：素反応 $k$ の活性化エネルギー

$h_{i}$ : 化学種 $i$ の比エンタルピー

$k$ : 火炎面の曲率

$\boldsymbol{P}$ ：応カテンソル (式(5))

$p$ : 圧力

$R_{0}$ : 一般気体定数

$R_{i}$ : 化学種 $i$ の気体定数

$S_{L} S_{T}$ : 層流燃焼速度, 乱流燃焼速度

$t$ : 時間

$T$ ：温度

$U$ ： 単位テンソル

$u$ : 速度

$V_{i}:$ 化学種 $i$ の拡散速度

$W_{i}:$ 化学種 $i$ の分子量

$w_{i}$ : 化学種 $i$ の反応速度

$X_{i}, Y_{i}$ : 化学種 $i$ のル分率と質量分率

$z$ ：火炎面

$\alpha_{k}$ : 素反応 $k$ の頻度因子中の温度の次数

$\Delta H$ ：熱発生率

$\delta_{\mathrm{L}}$ : 層流火炎厚さ

$\lambda ：$ 混合気体の熱伝導率

$\mu$ ：混合気体の粘性係数

$v_{i, k}^{\prime} v^{\prime \prime}{ }_{i, k}$ : 素反応 $k$ における化学種 $i$ の反応物及 び生成物としての化学量論係数 $\rho, \rho_{i}$ : 混合気の密度, 化学種 $i$ の密度

$\tau_{\mathrm{F}}, \tau_{l}$ : 火炎の時間スケール, 乱流場の時間ス ケール

\section{3. 水素・空気乱流予混合火炎の直接数值計算}

3.1 基礎方程式本研究では, 外力, Soret 効果, Dufour 効果, 圧力勾配拡散, 体積粘性及び放射熱流束 が無視できると仮定し，次のような質量，運動量，工 ネルギー及び化学種の保存方程式と状態方程式を基礎 方程式とする(14).

$$
\begin{aligned}
& \frac{\partial \rho}{\partial t}+\nabla \cdot[\rho u]=0, \\
& \frac{\partial \rho u}{\partial t}+\nabla \cdot[\rho u u]=-\nabla \cdot P, \\
& \frac{\partial \rho T}{\partial t}+\nabla \cdot[\rho u T]=\frac{1}{\bar{c}_{v}} \nabla \cdot[\lambda \nabla T] \\
& \quad-\frac{1}{\bar{c}_{v}} \sum_{i=1}^{N}\left(\rho Y_{i} V_{i} c_{p, i} \nabla T\right)-\frac{T}{\bar{c}_{v}} \sum_{i=1}^{N}\left[R_{i} \nabla \cdot\left(\rho Y_{i} V_{i}\right)\right] \\
& \quad-\frac{1}{\bar{c}_{v}} \boldsymbol{P}:(\nabla u)-\frac{1}{\bar{c}_{v}} \sum_{i=1}^{N}\left(h_{i} w_{i}\right)+\frac{T}{\bar{c}_{v}} \sum_{i=1}^{N}\left(R_{i} w_{i}\right), \\
& \frac{\partial Y_{i}}{\partial t}+\boldsymbol{u} \cdot \nabla Y_{i}=-\frac{1}{\rho} \nabla \cdot\left(\rho Y_{i} V_{i}\right)+\frac{w_{i}}{\rho}, \\
& i=1,2, \cdots, N
\end{aligned}
$$

ここで,

$$
\begin{aligned}
\boldsymbol{P}= & {\left[p+\frac{2}{3} \lambda(\nabla \cdot \boldsymbol{u})\right] \boldsymbol{U}-\mu\left[(\nabla \boldsymbol{u})+(\nabla \boldsymbol{u})^{T}\right] } \\
q= & -\lambda \nabla T+\sum_{i=1}^{N} h_{i} Y_{i} V_{i}, \\
\bar{c}_{v}= & \sum_{i=1}^{N} c_{v, i} Y_{i}, \\
w_{i}= & W_{i} \sum_{i=1}^{N}\left(v_{i, k}^{\prime \prime}-v_{i, k}^{\prime}\right) B_{k} T^{\alpha_{k}} \\
& \times \exp \left(-\frac{E}{R^{0} T}\right)_{i=1}^{N}\left(\frac{X_{i} p}{R^{0} T}\right)^{v_{i, k}^{\prime}}, \\
p= & \rho R^{0} T \sum_{i=1}^{N}\left(\frac{Y_{i}}{W_{i}}\right), \quad i, 2, \cdots, N \\
R_{i}= & \frac{R^{0}}{W_{i}}, \quad i=1,2, \cdots, N \\
X_{i}= & \frac{Y_{i} / W_{i}}{\sum_{j=1}^{N}\left(Y_{j} / W_{j}\right)}, \quad i=1,2, \cdots, N
\end{aligned}
$$

である。

3. 2 計算方法 本研究では, 二次元一様等方性 乱流中を伝播する水素 · 空気乱流予混合火炎を対象と ᄂ, $\mathrm{H}_{2}, \mathrm{H}, \mathrm{O}_{2}, \mathrm{O}, \mathrm{OH}, \mathrm{HO}_{2}, \mathrm{H}_{2} \mathrm{O}_{2}, \mathrm{H}_{2} \mathrm{O}, \mathrm{N}, \mathrm{NO}$, $\mathrm{NO}_{2}, \mathrm{~N}_{2}$ の 12 種類の化学種と 27 の素反応からなる詳 


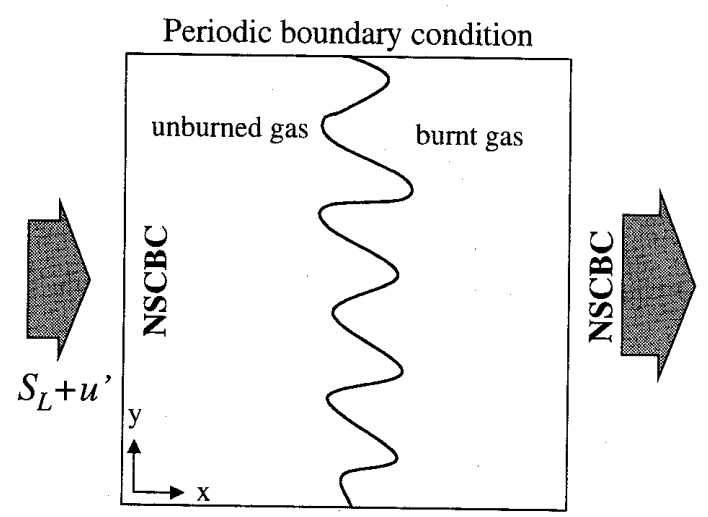

Periodic boundary condition

Fig.1 Geometry of the flow field used in the present study.

Table 1 Numerical parameters of direct numerical simulations of hydrogen-air turbulent premixed flames.

\begin{tabular}{|c|c|c|c|c|c|}
\hline No. & $u_{\text {rus }^{\prime}}^{\prime} / S_{L}$ & $R e_{t}$ & $R e_{\lambda}$ & $l / \delta_{L}$ & $N_{x} \times N_{y}$ \\
\hline 1 & 10.0 & 535 & 203 & 4.88 & $789 \times 512$ \\
\hline 2 & 20.0 & 1303, & 401 & 4.84 & $1153 \times 768$ \\
\hline 3 & 30.0 & 1971 & 595 & 4.82 & $1537 \times 768$ \\
\hline
\end{tabular}

細化学反応機構(15)を用いた，反応速度と物性值及び輸 送係数の温度依存性はChemkin'(16)(17)を用いて与えた。 ただし，Chemkin はベクトル化と並列化が容易に行え るように変更されている.

図 1 は本研究で対象とした流れ場を示している。離 散化は流れ方向 ( $x$ 方向) には 4 次精度中心差分, 流 れと垂直方向 ( $y$ 方向) にはスペクトル法を用いて行 い, 時間前進には 2 次精度 Adams-Bashforth 法を用い

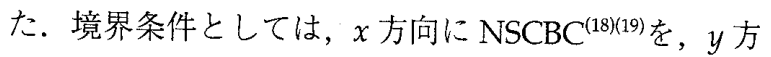
向に周期的境界条件を用いた。流入条件における混合 気としては, $0.1 \mathrm{MPa}, 298.15 \mathrm{~K}$, 当量比 1.0 の水素と空 気の予混合気を与えた。未然予混合気は窒素により希 釈されており，窒素と酸素のモル分率比は9.37とした。

流入速度条件は次のように与えた。

$$
u_{\text {in }}(y, t)=S_{L}+u^{\prime}(y, t)
$$

ここで，故は十分発達した二次元一様等方性乱流の速 度場である。また，次のように定義される層流燃焼速 度は $0.462 \mathrm{~m} / \mathrm{s}$ であり, 一次元層流予混合火炎の予備 計算により決定した。

$$
S_{L}=-\frac{1}{\rho_{\psi} Y_{\mathrm{H}_{2}, u}} \int w_{\mathrm{H}_{2}} d x
$$

ここで，下付き添字 $\mathrm{u}$ は末燃側の物理量を示す。また， 次のように定義される層流火炎厚さは $3.08 \times 10^{4}(\mathrm{~m})$ で ある。

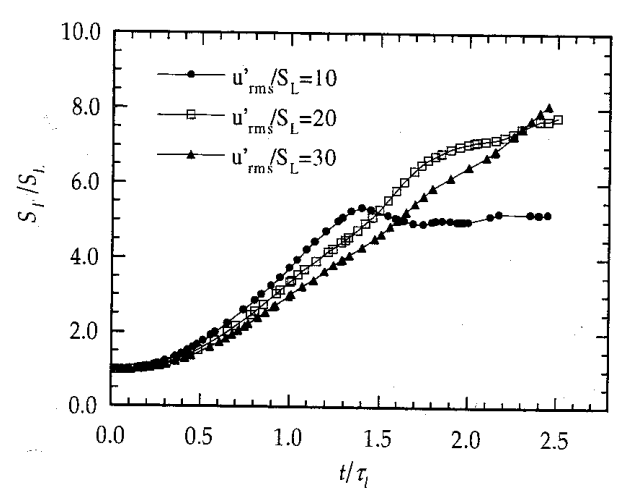

Fig.2 Developments of turbulent burning velocity.

$$
\delta_{L}=\left(T_{b}-T_{u}\right)\left(\frac{\partial T}{\partial x}\right)_{\text {max }}
$$

ここで，下付き添字 $\mathrm{b}$ は既燃側の物理量を示す。一様 等方性乱流の速度場には，初期条件の影響が無くなり 十分発達した 1 eddy turnover time $\left(\tau_{l}=l_{0} / u_{r m s, 0}^{\prime}\right) に お け$ る結果を用いた。ここで， $l_{0}$ は初期積分長， $u_{r m s, 0}^{\prime}$ は初 期二乗平均速度である。二方向に周期的境界条件のも とで計算された乱流場は, Taylorの仮説と位相シフト 法を用いて初期及び流入乱流場へと変換した。

計算は $2 \mathrm{~cm} \times 2 \mathrm{~cm}$ の領域を対象とし, 表 1 に示すよ うな条件で計算を行った．表中の $R e_{l}$ は積分長に基づ くレイノルズ数であり, Re $e_{\lambda}$ なイラー・マイクロスケ 一ルに基づくレイノルズ数である。また， $N_{x}$ と $N_{y}$ は それぞれ $x$ 方向と $y$ 方向の格子点数である. 本研究で は, 積分長と層流火炎厚さの比を約 4.8 に固定し, 層 流燃焼速度に対する乱流強度の比が 10.0，20.0 及び 30.0 の場合について計算を行った。

\section{4. 高強度乱流予混合火炎の構造}

4. 1 火炎構造図 2 は次のように定義される乱 流燃焼速度の時間変化を示している。

$$
S_{T}=-\frac{1}{\rho_{u} Y_{H_{2}, u} L_{y}} \iint w_{H_{2}} d x d y .
$$

ここで，時間 $t$ は初期乱流場の eddy turnover timeを 用いて無次元化されている。図 2 から， $t>2.3 \tau_{1}$ では乱 流強度の増加とともに乱流燃焼速度は増大しているこ とがわかる，初期過程 $\left(t<1.4 \tau_{l}\right)$ では，最も乱流強度の 低い $u_{r m s}^{\prime} / S_{L}=10.0$ の場合の方が $u^{\prime}{ }_{r m s} / S_{L}=20.0$ と 30.0 の高乱流強度の場合よりも大きな乱流燃焼速度を示し ている. $u_{r m s}^{\prime} / S_{L}=10.0$ の場合，乱流燃焼速度は $t=1.4 \tau_{l}$ に㧍いてピークを示した後, 約 $5.1 S_{L}$ でほぼ一定となっ ている. $u_{r m s}^{\prime} / S_{L}=20.0$ と 30.0 の場合, 乱流然焼速度は, 本計算の期間内で上昇し続けている. $u_{r m s}^{\prime} / S_{L}=30.0$ の 場合の乱流燃焼速度は, $t=2.3 \tau_{l}$ において $u_{r m s}^{\prime} / S_{L}=20.0$ 
(a)

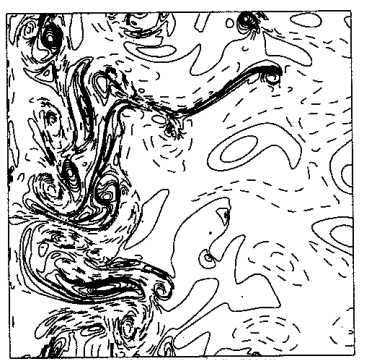

(b)

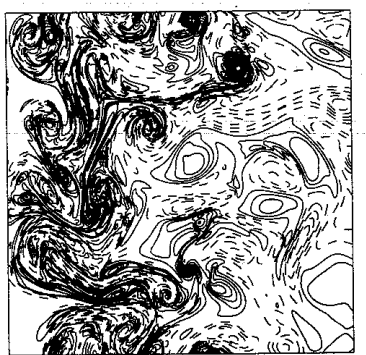

(c)

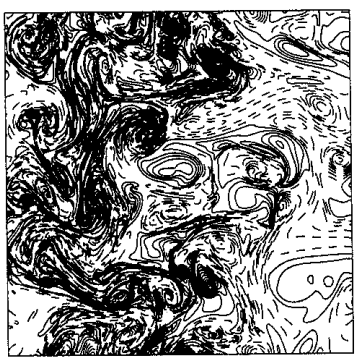

$\omega$
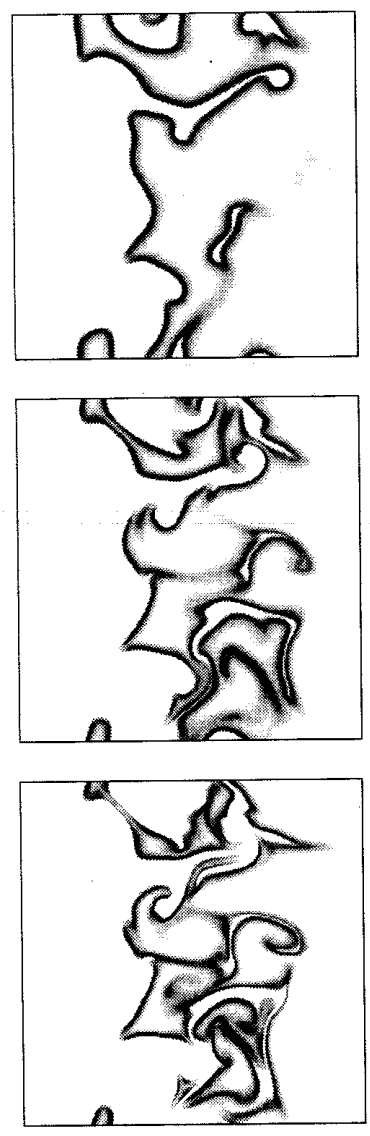

$\Delta H$
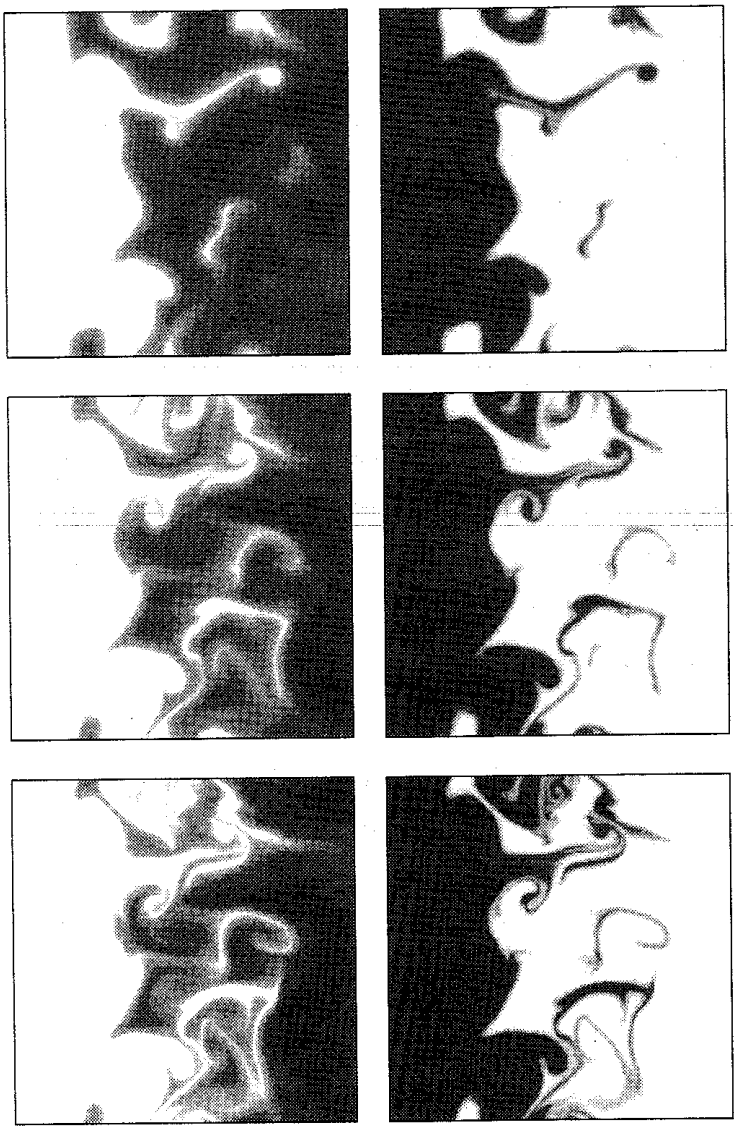

$T$

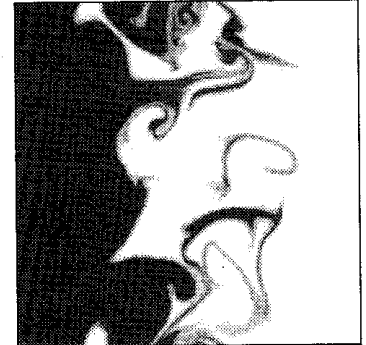

$\rho$

Fig.3 Distributions of vorticity, heat release rate, temperature and density at $t=2.0 \tau_{l}$. (a): $u_{r m s}^{\prime} / S_{L}=10.0,(\mathrm{~b}): u_{r m s}^{\prime} / S_{L}$ $=20.0$, (b): $u_{r m s}^{\prime} / S_{L}=30.0$.

の場合よりも大きくなり，計算の最終時刻においては 約 $8.1 S_{L}$ となっている. 本研究では, $t=2.0 \tau_{l}$ の計算結 果を用いて, 乱流子混合火炎の諸特性に対する乱流強 度の影響を検討する。

図 3 は, $t=2.0 \tau$ における渦度, 熱発生率, 温度及び 密度の分布を示している。ここで，渦度の等値線は， 実線が正の值を，破線が負の值を示している。また， 等值線の間隔は, $u^{\prime}{ }_{r m s} / S_{L}=10.0$ の場合 $\Delta \omega=3,000[1 / \mathrm{s}]$, $u^{\prime}{ }_{r m s} / S_{L}=20.0$ の場合 $\Delta \omega=6,000[1 / \mathrm{s}], u_{r m s}^{\prime} / S_{L}=30.0$ の 場合 $\Delta \omega=9,000[1 / \mathrm{s}]$ である. 熱発生率, 温度及び密度 の分布は，白が最小值，黒が最大值に対応する。すべ ての場合について，未然側に存在する渦は火炎面を通 過する際に急速に減衰しているが, 以前の低乱流強度 の場合 ${ }^{(5)(6)}$ に比べて, 未燃側の渦は既燃側深くまで侵入 し，火炎面を複雑に湾曲させている。 $u^{\prime}{ }^{\prime}{ }^{\prime} / S_{L}=10.0$ の 場合，火炎面は大きく湾曲しているが，此較的滑らか で連続的に変化している。このことから， $u^{\prime}{ }_{m s} / S_{L}=10.0$ の場合に形成される火炎面は wrinkled laminar flame の領域にあると考えられる。これに対して， $u^{\prime}{ }^{\prime}{ } / S_{L}$ の増加とともに，火炎面は火炎面付近に存在する強い 渦に巻き达まれるようになりより複雑な形状を有し
ている。このように $u^{\prime}{ }_{m s} / S_{L}$ の増加とともに局所的な 火炎面の複雑さは増すが, 火炎面が存在している火炎 帯の幅は $u^{\prime}{ }_{m s} / S_{L}$ に大きく依存しない。

また，すべての場合について既燃側に分離された末 燃予混合気塊が形成されている。これらの未燃予混合

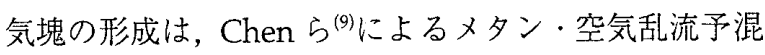
合火炎の DNS においても報告されている．既然側の 未燃予混合気塊の形状は, $u_{r m s}^{\prime} / S_{L}$ の増加とともに複雑 な形状を示し，より細く長い形状を持つようになる。 これは， $u^{\prime}{ }_{m s} / S_{L}$ が大きいほど，末然予混合気塊周囲に 存在する渦の強度が強くなるためである。

図 4 は， $u_{r m s}^{\prime} / S_{L}=30.0$ の場合について, 未燃予混合 気塊が存在する領域付近の熱発生率, 渦度及び次のよ うな渦度輸送方程式のバロクリニック・トルク項の分 布を示している。

$$
\begin{aligned}
\frac{D \omega}{D t}=(\omega \cdot \nabla) u-\omega(\nabla u) & +\frac{\nabla \rho \times \nabla p}{\rho^{2}} \\
& +\mu \nabla^{2} \omega+\nabla^{2} u \times \nabla \mu,
\end{aligned}
$$

ここで, 右辺第三項がバロクリニック・トルク項であ る.また，右辺第一項は二次元場を対象としているた め零であり，第二項の膨張項，第四項と第五項の粘性 


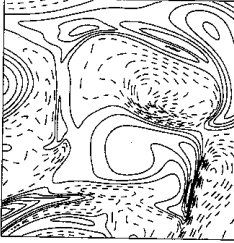

$\omega$

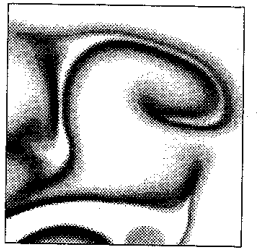

$\Delta H$

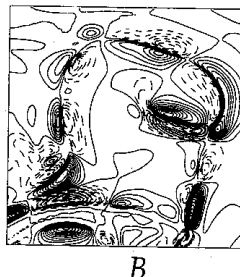

$B$
Fig.4 Magnified views of heat release rate, vorticity and Baroclinic torque near the unburned pocket for $u^{\prime}{ }_{r m s} / S_{L}=30.0$ at $t=2.0 \tau_{l}$.

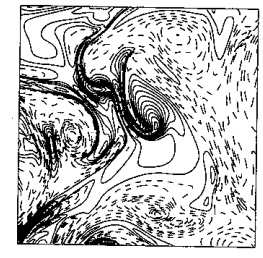

$\omega$

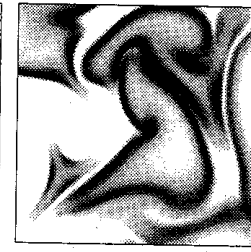

$\Delta H$

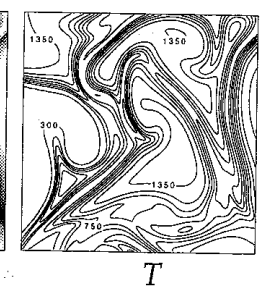

Fig.5 Magnified views of heat release rate, vorticity and temperature where the flame front becomes very complicated for $u_{r m s}^{\prime} / S_{L}=30.0$ at $t=2.0 \tau_{l}$.

項はバロクリニック・トルク項に此ベて非常に小さい. 未燃予混合気塊の周囲で，渦度は比較的大きな值を示 し，未燃予混合気塊を取り囲むように，大きなバロク リニック・トルクが発生している。バロクリニック． トルクの分布と渦の外縁部は比較的良く対応して扮り， このバロクリニック・トルクによる渦度の生成により， 既燃側での渦度の減衰が抑制されるとともに渦形状も 変化する。

図 5 は, $u_{r_{m}}^{\prime} / S_{L}=30.0$ の場合について, 火炎面が非 常に複雑となる領域における渦度, 熱発生率及び温度 の分布を示している。熟発生率の分布から，火炎面が 幾重にも折り畳まれていることがわかる。ささらに，火 炎面が大きく湾曲した部分に扔いて熱発生率は急激に 減少し, 局所的な消炎が起こっている。これらの局所 消炎は同程度の $u_{r m s}^{\prime} / S_{L}$ のメタン・空気乱流予混合火 炎においても観察されており ${ }^{(11)}$ ，非常に強い渦運動に 起因して火炎面に作用する大きな歪み速度によって生 じている。またこのように火炎面が折り畳まれた領 域では，温度は比較的高い値を示す。このような火炎 構造は, $u_{r m s}^{\prime} / S_{L}=30.0$ の場合に形成される火炎が wrinkled laminar flameの領域ではなく, 高乱流強度 の場合に予測されている distributed reaction zoneの 領域に分類されることを示唆している.

\section{2 火炎要素の統計的性質 局所的な火炎構造} に対する $u_{r m s}^{\prime} / S_{L}$ の影響を明らかにするために，DNS 結果から局所的な火炎要素を抽出し，それらの統計的 性質を検討する。本研究では，次のように火炎面を定 義した。

$$
z=\left(\frac{\partial T}{\partial n}\right)_{\max },
$$

ここで, $n$ は火炎面に対して法線方向の単位ベクトル
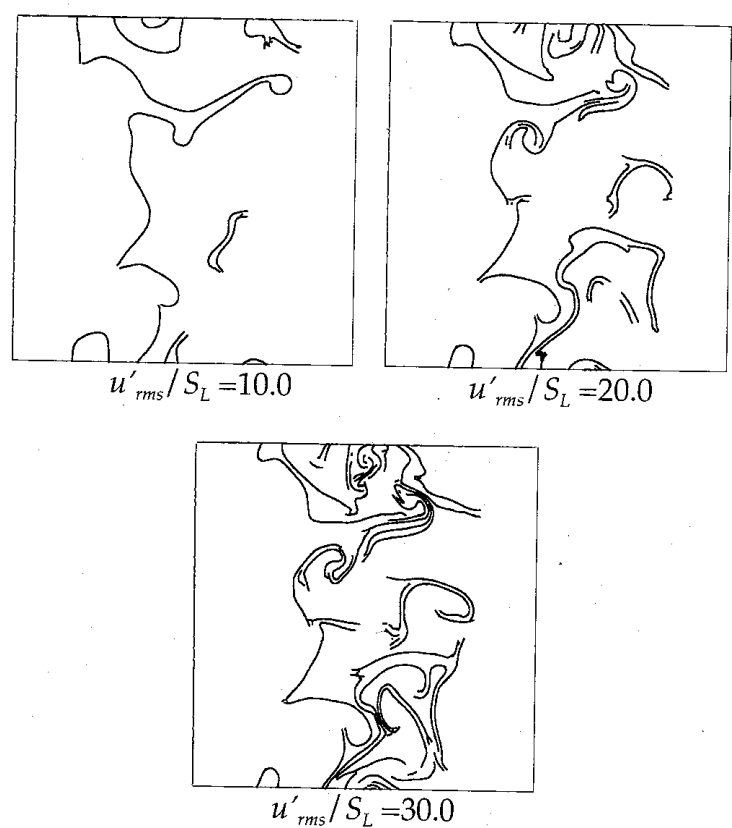

Fig.6 Flame fronts defined by the local temperature gradients at $t=2.0 \tau_{1}$.

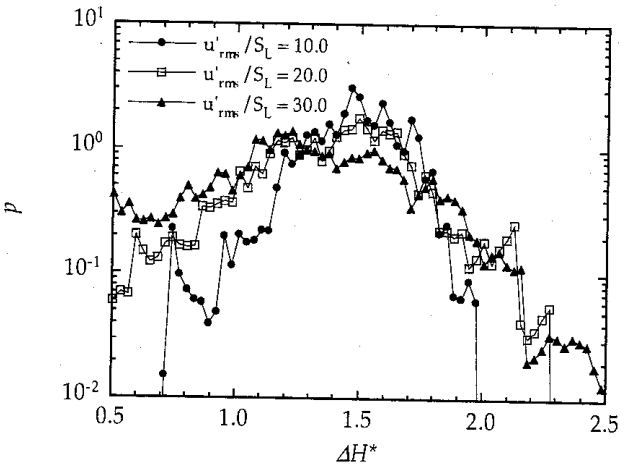

Fig.7 Probability density functions of the maximum heat release rate in the local flame element in turbulence at $t=2.0 \tau$.

である.図6はそれぞれの場合について $t=2.0 \tau_{l}$ の DNS 結果加決定された火炎面を示している。決定された 火炎面は，図３に示した温度と密度が急激に変化する 位置と非常に良く対応している.図 5 に示したように, $u_{r m s}^{\prime} / S_{L}$ の増加とともに火炎構造は複雑となり, 局所的 な消炎により火炎面は不連続となる。火炎面が不連続 となる領域で, 温度勾配は層流火炎の 30\%以下に低下 し，それらを火炎面として取り扱うことは困難となる。

図 7 は, 各火炎要素の最大熱発生率の確率密度関数 を示している.ここで, 最大熱発生率は層流火炎の最 大熱発生率 $\left(\Delta H_{L}\right)$ を用いて無次元化されている. 以下， ※を付した物理量は層流燃焼速度, 層流火炎厚さ及び層 流火炎の最大熱発生率を用いて無次元化されている. すべての場合について, 最大熱発生率の確率密度関数 がピークを示す值は，層流火炎の熱発生率よりも大き い. しかし, $u_{r m s}^{\prime} / S_{L}$ の増加とともに, 熱発生率の最頻 值は小さくなる傾向にあり， $u_{r m s}^{\prime} / S_{L}=30.0$ の場合には 


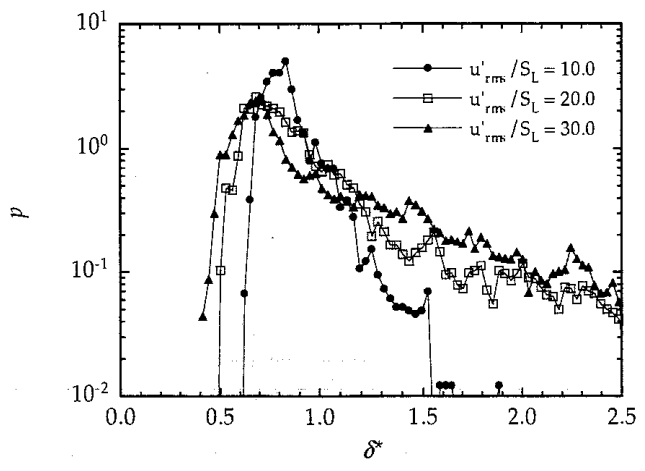

Fig.8 Probability density functions of the flame thickness of the local flame element in turbulence at $t=2.0 \tau_{l}$.

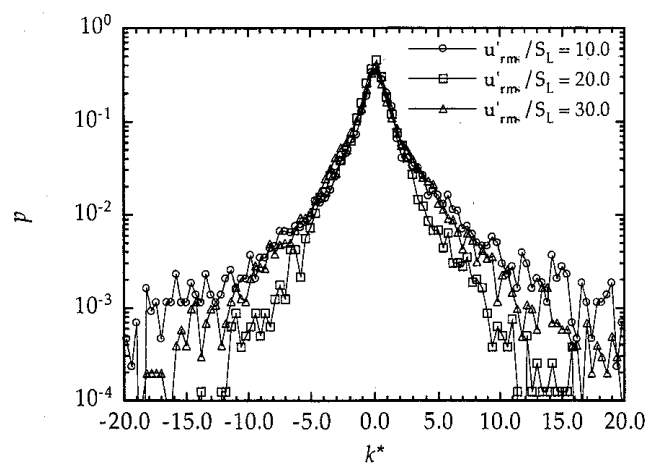

Fig.9 Probability density functions of the curvature of the flame front in turbulence at $t=2.0 \tau$.

層流火炎の約 1.2 倍である.このように $u^{\prime}{ }_{r m s} / S_{L}$ の増加 とともに熱発生率の最頻值は減少するが，熱発生率の 分散は大きくなる。また，火炎要素の熱発生率の最大 值は $u_{r m s}^{\prime} / S_{L}$ の増加とともに大きくなり, $u_{r m s}^{\prime} / S_{L}=30.0$ の場合には層流火炎の約 2.5 倍と非常に大きな熱発生 率を持つ火炎要素が存在する，小さな熱発生率を示す 火炎要素の存在確率も $u^{\prime}{ }_{r m} / S_{L}$ の増加とともに増加し, 最も大きな $u_{r m s}^{\prime} / S_{L}$ の場合では層流火炎の $50 \%$ 程度の 熱発生率を持つ火炎要素の存在確率が比較的高くなる。 火炎面に沿って平均した熱発生率は， $u_{r m s}^{\prime} / S_{L}=10.0$, 20.0，30.0の場合に対してそれぞれ $1.5 \Delta H_{L}, 1.2 \Delta H_{L}$ 及び $0.92 \Delta H_{L}$ であり, 乱流強度が高いほど平均的には 小さな熱発生率を示すが, 上述のように個々の火炎要 素の熱発生率は大きく異なる。

図 8 は，次のように定義される局所火炎厚さの確率 密度関数を示している。

$$
\delta=\left(T_{b}-T_{u}\right) /\left(\frac{\partial T}{\partial n}\right)_{\max },
$$

ここで，図中の火炎厚さは層流火炎の火炎厚さを用い て無次元化されている. 乱流中の火炎厚さの最頻値は, $u^{\prime}{ }_{r m s} / S_{L}=10.0$ の場合約 $0.85 \delta_{L}$ であり， $u^{\prime}{ }_{r m s} / S_{L}$ の増加と ともに減少する.すなわち, 乱流強度が高い場合ほど, 薄い火炎要素が形成されるようになる，さらに，最小
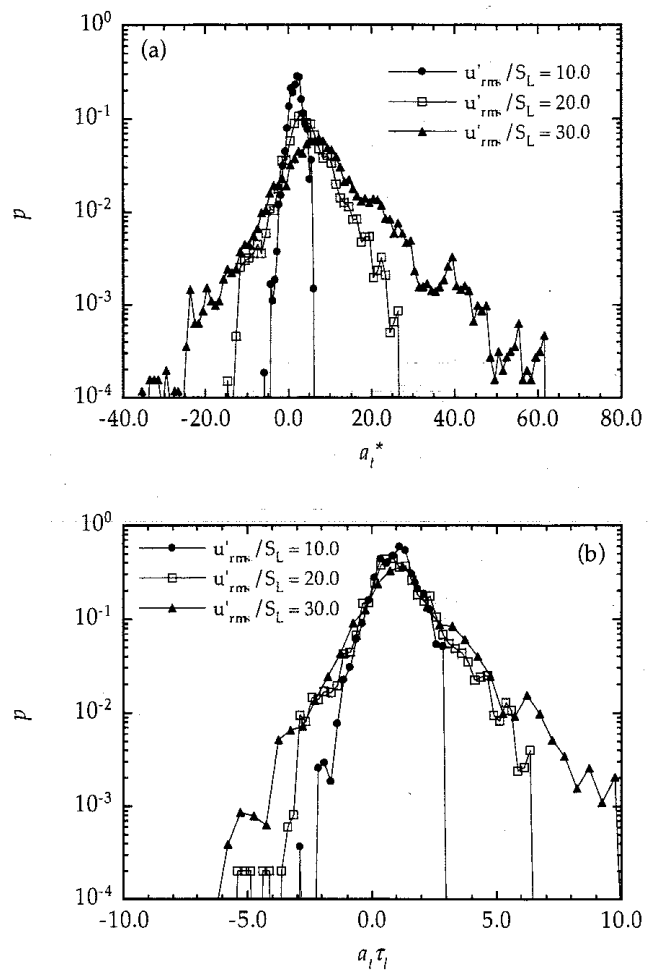

Fig.10 Probability density functions of the tangential strain rate at the flame front in turbulence at $t=2.0 \tau$. (a): the tangential strain rate is normalized by the flame time, (b): is normalized by the eddy turnover time.

火炎厚さも $u_{r m s}^{\prime} / S_{L}$ の增加とともに小さくなり, $u^{\prime}{ }_{r m s} / S_{L}=30.0$ の場合には層流火炎の半分以下の厚さを 持つ非常に薄い火炎要素が形成されている。 また， $u_{r m s}^{\prime} / S_{L}$ の増加とともに, 厚い火炎要素の存在確率も増 加する。このため, 平均火炎厚さは， $u_{r m s}^{\prime} / S_{L}=10.0$, $20.0 ， 30.0$ の場合に対してそれぞれ $0.85 \delta_{L}, 0.93 \delta_{\mathrm{L}}$ 及 び $0.97 \delta$ となり, 乱流強度が高いほど火炎厚さの平均 值は大きくなる。

$t=2.0 \tau$ における火炎長さは, $u_{r m s}{ }_{r} / S_{L}=10.0,20.0,30.0$ のそれぞれの場合に対して平面層流火炎長さの約 3.6 倍， 6.5 倍及び 8.1 倍である。しかし，図 2 に示したよ うに，乱流燃焼速度は火炎長さの増大ほど上昇してい ない。これは，上述のように乱流中での火炎要素の特 性が層流火炎と大きく異なるためである。

図 9 は火炎面の曲率の確率密度関数を示している. ここで，曲率は既然側に凸を正とした。すずての場合 について，曲率の確率密度関数はほぼ零でピークを示 しており，曲率の絶対值が小さな範囲 $\left(\left|k^{*}\right|<5\right) て ゙ は ，$ $u_{r m s}^{\prime} / S_{L}$ が異なっても確率密度関数は非常に良く一致 している。曲率の絶対值が大きな火炎要素の確率は $u^{\prime}{ }_{m s} / S_{L}$ に依存しているが， $u_{r m s}^{\prime} / S_{L}$ に対する明確な傾 向は観察されない。

図 10 は,乱流運動により火炎面の接線方向に作用す 

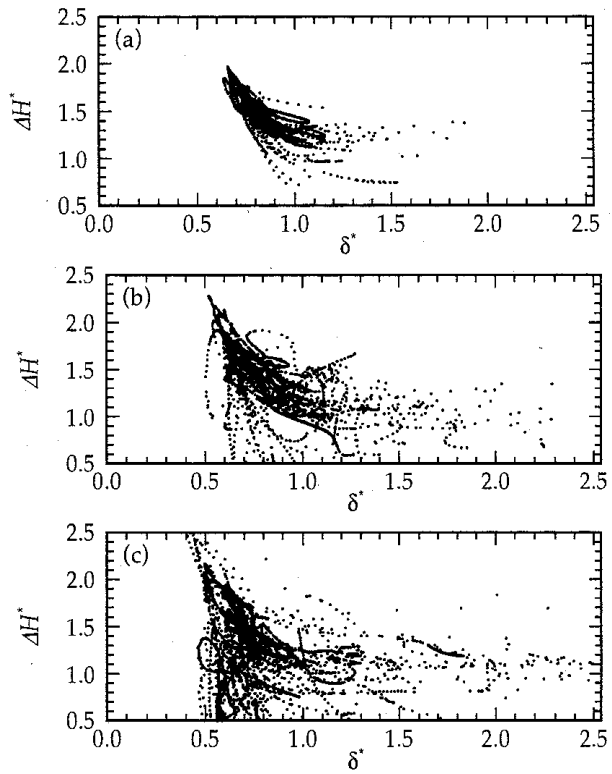

Fig.11 Scatter plots of local heat release rate and the local flame thickness at $t=2.0 \tau_{l}$. (a): $u_{r m s}^{\prime} / S_{L}=10.0$, (b): $20.0,(c): 30.0$.
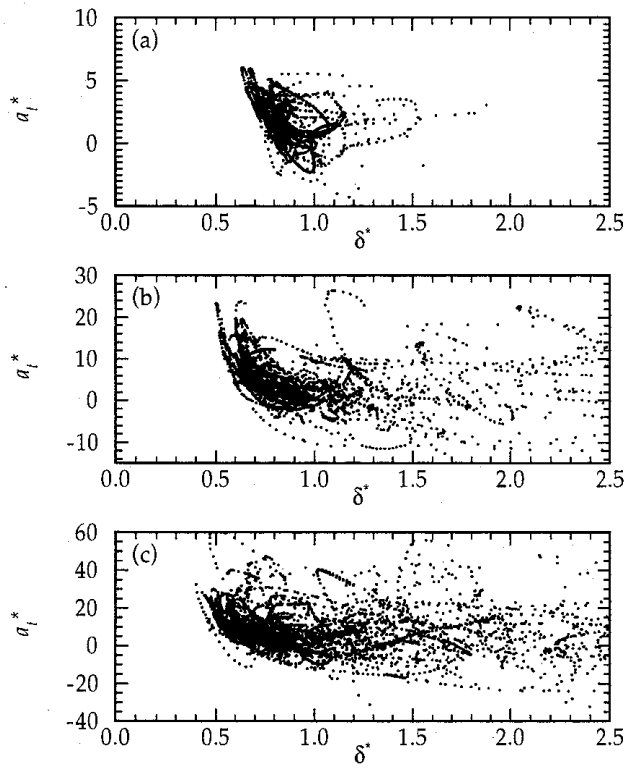

Fig.12 Scatter plots of tangential strain rate and the local flame thickness at $t=2.0 \tau_{l}$. (a): $u_{r m s}^{\prime} / S_{L}=10.0$, (b): 20.0, (c): 30.0 .

る歪み速度の確率密度関数を示している．接線方向歪 み速度は次のように定義される(20)。

$$
a_{t}=t t: \nabla u,
$$

ここで， $t$ は火炎面に対して接線方向の単位べクトル である。接線方向歪み速度は伸張を正とし，図 10(a) では層流火炎厚さと層流燃焼速度を用いて，図 10(b) では乱流強度と積分長を用いて無次元化されている。 これらは,それぞれ火炎の時間スケール $\left(\tau_{\mathrm{F}}=\delta_{L} / S_{L}\right)$ と乱 流場の時間スケール $\left(\tau_{l}\right)$ の逆数を用いて無次元化した ことに対応する。図 10(a)加，火炎面に作用する接線
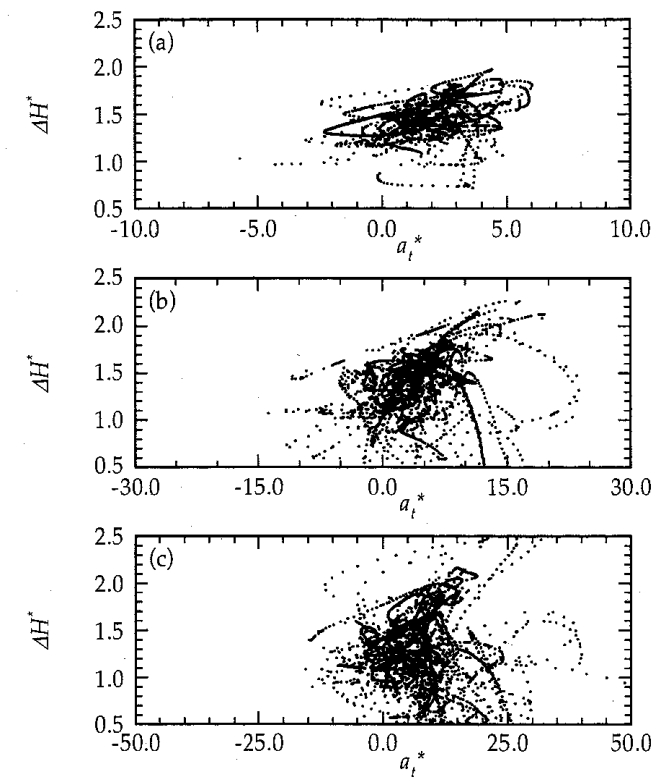

Fig.13 Scatter plots of heat release rate and tangential strain rate at the flame front at $t=2.0 \tau_{1}$. (a): $u^{\prime}{ }_{r m s} / S_{L}=$ 10.0, (b): 20.0, (c): 30.0 .

方向歪み速度の確率密度関数は, 正の值でピークを示 して扔り，平均的に火炎面が接線方向に伸張を受けて いることがわかる.また, $u^{\prime}{ }_{r m s} / S_{L}$ の増加とともに確率 密度関数がピークを示す歪み速度とその分散は大きく なる．図 10(b)に示したように，乱流強度が異なる場合 でも接線方向歪み速度の最頻值は，乱流場の時間久ケ ールを用いて整理することができ，ほぼ $a_{t}=1 / \tau_{l}$ となる。 この場合, 歪み速度の確率密度関数の形状もほぼ一致 する。

図 11 は火炎要素の最大熱発生率と火炎厚さの関係 を示している。すべての場合について，薄い火炎要素 ほど大きな熱発生率を示す傾向にあることがわかる。

また, $u^{\prime}{ }_{m s} / S_{L}$ の増加とともに最も大きな熱発生率を示 す火炎要素は薄くなり，それらの熱発生率も大きくな る. ${u^{\prime}{ }_{r s}} / S_{L}=30.0$ の場合, 最も薄い火炎要素の厚さは $0.4 \delta_{L}$ であり，2.5AH $H_{L}$ 以上の非常に大きな熱発生率を示 す。しかし，乱流強度が強いほど，火炎厚さが比較的 薄く, 小さな熱発生率を示す火炎要素の存在確率も増 加している.図 12 は局所火炎厚さと接線方向歪み速度 の関係を示している。乱流中での火炎要素の厚さは, 火炎面に作用する接線方向歪み速度と強い相関があり， 薄い火炎要素ほど接線方向に強い伸張を受けている。 ただし， $u_{r m s}^{\prime} / S_{L}$ が大きいほど，同じ大きさの接線方向 歪み速度が作用している火炎要素であっても，火炎厚 さの分散は大きくなる。

図 13 は局所熱発生率と接線方向歪み速度の関係を 示している．以前の低乱流強度の場合と同様に(5)(6)，火 炎要素の熱発生率と接線方向歪み速度の間には明確な 相関があり，伸張を受けた火炎要素ほど大きな熱発生 
率を示す。しかし，図 11 に示した火炎厚さと同様に， $u^{\prime}{ }_{m s} / S_{L}$ の増加とともに大きな接線方向歪み速度を受 けていながら，小さな熱発生率を示す火炎要素の存在 確率も增加している.これは, 以前のメタン・空気乱

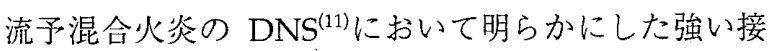
線方向歪み速度による乱流予混合火炎の局所消炎によ るものである。

以前の低乱流強度予混合火炎に関する研究(5)(6)にお いて, 火炎面の曲率と局所熱発生率の間に明確な相関 が存在することを明らかにした。しかし，本研究で対 象とした高乱流強度の場合，火炎面の曲率と局所熱発 生率の間に明確な相関は存在しない.

\section{5. 結論}

本研究では、乱流予混合火炎の火炎構造に対する乱 流強度の影響を明らかにするために，窒素によって希 釈した当量比 1 の水素・空気乱流予混合火炎の直接数 値計算を行い，以下のような結論を得た。

(1) $u_{r m s}^{\prime} / S_{L}=10.0$ の乱流予混合火炎の火炎面は比較 的滑らかで，かつ連続的であり，wrinkled laminar flames に分類できる. $u^{\prime}{ }_{r m s} / S_{L}$ の増加とともに, 火炎面 は複雑さを増し, $u^{\prime}{ }_{r m s} / S_{L}=30.0$ の場合の火炎面は distributed reaction zone に分類できる。

（2）乱流強度の増加とともに，乱流中での最小火炎 厚さは減少し, 最大熱発生率と火炎長さは増加する。 しかし, 高乱流強度の場合, 火炎厚さが厚く小さな熱 発生率を示す火炎要素が形成されるため, 乱流強度の 増加とともに平均火炎厚さは厚くなり, 平均熱発生率 は低下する。

（3）高乱流強度の場合, 局所熱発生率と局所火炎厚 さ及び接線方向歪み速度の間に強い相関があり，火炎 厚さが薄く接線方向に強い伸張を受けた火炎要素ほど 大きな熱発生率を示す。

\section{文 献}

(1) F. A. Williams, Combustion Theory, 2nd ed, Benjiamin Cummings, (1985).

(2) T. J. Poinsot, D. Veynante and S. Candel, Diagrams of Premixed Turbulent Combustion based on Direct Simulation, 23rd Symp. (Int.) Combust., The Combustion Institute, (1990), 613 619.

(3) M. Baum, T. J. Poinsot, D. C. Haworth and N. Darabiha, Direct Numerical Simulation of $\mathrm{H}_{2} / \mathrm{O}_{2} / \mathrm{N}_{2}$ Flames with Complex Chemistry in Two-Dimensional Turbulent Flows, J. Fluid Mech., 281 (1994), $1 \sim 32$.

(4) T. Miyauchi, M. Tanahashi, Y. Imamura and Y. Nada, Structure and Fractal Characteristics of $\mathrm{H}_{2}$-Air Turbulent Premixed Flames, Proc. 1st Asia-Pacific Conf. Combust., (1997) $278 \sim 281$.
（5）店橋 - 宮内 - 名田 - 今村，水素 - 空気乱流予混合火炎の局 所構造，日本機械学会論文集(B 編)，64-624 (1998)，2662 2668.

（6）店橋 ·宮内 ·名田，水素 - 空気乱流予混合火炎に扔ける乱 流と火炎の相互作用，燃焼の科学と技術，6 suppl. (1998), 13 22.

（7）宮内 - 店橋 - 名田，水素 - 空気乱流予混合火炎の局所構造， 第 34 回伝熱シンポジウム講演論文集, (1997) 583～584.

(8) T. Echekki and J. H. Chen, Unsteady Strain Rate and Curvature Effects in Turbulent Premixed Methane-Air Flames, Combust. Flame, 106 (1996), 184 202.

(9) J. H. Chen, T. Echekki and W. Kollmann, The Mechanism of Two-dimensional Pocket Formation in Lean Premixed Methane-Air Flames with Implications to Turbulent Combustion, Combust. Flame, 116 (1998), 15 48.

(10) D. Haworth, B. Cuenot, T. Poinsot and R. Blint, Numerical Simulation of Turbulent Propane-Air Combustion with Non-Homogeneous Reactants, Bulletin of the American Physical Society, 43-9 (1998), 2062.

(11) M. Tanahashi, T T. Miyauchi, T. Saito and M. Shimamura, Local Extinction and $\mathrm{NO}_{x}$ Formation in Methane-Air Turbulent Premixed Flames, Proc. 2nd Asia-Pacific Conf. Combust., (1999) 500 503 .

(12) 店橋 · 宮内 ·名田，水素 ·空気乱流予混合火炎の三次元構 造，第 35 回伝熱シンポジウム講演論文集，(1998)，545一 546.

(13) M. Tanahashi, T. Miyauchi and Y. Nada, Fine Scale Structure of $\mathrm{H}_{2}$-Air Turbulent Premixed Flames, Turbulence and Shear Flow Phenomena-1, Eds. S. Banaerjee \& J. K. Eaton, Begell House Inc., (1999), 59 64.

(14) T. Miyauchi, M. Tanahashi, K. Sasaki and T. Ozeki, Vortex-Flame Interaction in Turbulent Diffusion flames, Transport Phenomena in Combustion 2, Ed. S. H. Chan, Taylor \& Francis, (1996) 1095 - 1105.

(15) E. Gutheil, G. Balakrishnan and F. A. Williams, Reduced Kinetic Mechanisms for Applications in Combustion Systems, Eds. N. Peter and B. Rogg, Springer-Verlag, (1993) $177 \sim 195$.

(16) R. J. Kee, F. M. Rupley and J. A. Miller, Chemkin-II: a Fortran chemical kinetics package for the analysis of gas phase chemical kinetics, Sandia Report, SAND89-8009B (1989).

(17) R. J. Kee, G. Dixon-Lewis, J. Warnatz, M. E. Coltrin and J. A. Miller, A Fortran computer code package for the evaluation of gas-phase multicomponent transport properties, Sandia Report, SAND86-8246 (1986).

(18) T. J. Poinsot and S. K. Lele, Boundary conditions for direct simulations of compressible viscous flows, J. Comput. Phys., 101 (1992), 104 129.

(19) M. Baum, T. Poinsot and D. Thevenin, Accurate Boundary Conditions for Multicomponent Reactive Flows, J. Comput. Phys., 116 (1994), 247 261.

(20) S. M. Candel and T. J. Poinsot, Flame Stretch and the Balance Equation for the Flame Area, Combust. Sci. Tech., 70 (1990), 1 15. 